\title{
COMMUNITY PARTICIPIATION IN VILLAGE DEVELOPMENT: THE SCALE OF LATVIA
}

\author{
Edgars PUDZIS ${ }^{1}$, Sanda GEIPELE ${ }^{2}$, Ineta GEIPELE ${ }^{3}$ \\ ${ }^{1-3}$ Riga Technical University, Latvia \\ Corresponding authore-mail: edgars.pudzis@edu.rtu.lv
}

\begin{abstract}
The research provides an insight into village development planning, as well as considers village planning from the perspective of the national planning framework. Local settings of village development have also been taken into account. The research provides information about possible approaches for local community involvement in development decision-making.

The article aims at considering the current situation of the involvement of local communities in the advancement of local territories and at presenting the proposals for public involvement models.

Analysis, logical and historical data access methods, induction and deduction have been used in the present research.
\end{abstract}

Keywords: Community development, community involvement, village planning.

\section{INTRODUCTION}

Over the past decades, after regaining the independence of the Republic of Latvia, significant changes have taken place in the country's development. First, it is worth mentioning that a democratic country has been established along with the development of a new legislative framework in order to ensure the development of the country, as well as major efforts have been undertaken to contribute to the development of civil society. Until now, many laws and regulations on development have been developed, as well as the documents of territorial development have been worked out at a national, regional and local (municipal) level. At the same time, by means of different instruments - activities of non-governmental organisations, state policy instruments, and the European Union support instruments, fundamental changes have occurred in the public attitude towards the involvement in the political and economic decision-making process at different levels.

Taking into account the positive changes as well as the necessity for a continuous process development, there is a need to promote the system of regional improvement in the direction that would make local communities at their lowest territorial levels participate more actively in the decision-making process as well as participate in the development of their areas.

The article aims at considering the current situation of the involvement of local communities in the development of local territories and at presenting the proposals for public involvement models. Within the framework of the research, the following tasks have been set: to examine the theoretical terms of community (village) existence at a local level, give insight into the national development planning 
system, and to analyse and present the proposals for the compliance of the public involvement models within the planning system.

Analysis, logical and historical data access methods, induction and deduction have been used in the research.

The main target group of the article is specialists of regional development planning at a national, regional and local level.

\section{THEORETICAL ASPECTS OF VILLAGE PLANNING}

\subsection{Village and Community}

In accordance with the Law on Administrative Territories and Populated Areas (Legislation of the Republic of Latvia, 2011), a village is one of the three types of inhabited areas (along with cities and farmsteads). The status of a village shall be granted and revoked by a municipality council, based on the local government territorial planning, in which the village border is defined and the need for developing a village is justified. The status of a village may be granted to such section of a municipality territory in which concentrated building is present (or is planned), people are living permanently, and the appropriate infrastructure has been developed. At the same time, the Law stipulates that the status of a village may also be granted to such section of district territory in which concentrated building is present or is planned, people are living permanently, and the appropriate infrastructure has been developed.

Jurgis Kavacs in his article "Village Concept Historical Development" (Kavacs, 2015) has stated that nowadays, a village is a certain rural area and it is not an administrative territorial unit as it was defined from 1945 to 1992 . However, to separate the inhabited areas of administrative territorial units is not always easy because both have a number of similar characteristics.

An inhabited area is a long-term, permanent or seasonal human settlement where the necessary material living conditions are created (housing and communications). The fact that rural areas are different by their structure is well known. However, a unified and generally accepted classification of rural settlements has not been made yet. It should be noted that in statistics during the 1930 s, the concept of rural village was used to refer to an individual inhabited building.

Historically, in the Latvian Conversation Dictionary (Latviešu Konversācijas vārdnīca, 1928), the "village" was defined as one of the several types of inhabited rural areas, whereas in the editions of Soviet times (Latvijas padomju enciklopedija, 1982), the word "village" was used to refer only to an administrative territorial unit.

M. Ušča in her Doctoral Thesis "Territorial Community Formation in Riga" (Ušča, 2013) has considered territorial communities:

"If the community-unifying factor is a common area, one can speak of territorial communities in the city. Thus, territorial communities are primarily characterised by a common territory and a certain attitude towards this area. In general, in human geography, the idea of urban communities is used as a specific category relating to one of the two signs: geographically or administratively united 
groups of people; common characteristics (e.g., interests, identity, etc.), which bring together individuals in one community.

The urban sociologist Margaret Kusenbah (Kusenbach, 2008) acknowledges that territorial communities can be defined in various ways - they may be different in size, structure, and scale; however, it is possible to distinguish three recognised and fundamental features that characterise all of them:

1) definite location (or: common territory);

2) common individual links (common interest, identity, etc.);

3) social interaction of individuals.

Definite location (or: common territory) - one of the characteristic features of territorial communities is a common territory. Unlike interest, ethical, etc., communities, the common area is the basis of territorial communities. The common area, first of all, can mean a common residence and related features - belonging to, identification with the definite location; secondly, the common use, care and responsibility of this area. Of course, not all the inhabitants of the territory are characterised by the above-mentioned features.

Common individual links - the feeling of connection with other inhabitants, described in various fields of science using such terms as "social capital", "social support", "neighbourhood cohesion", "place attachment", "sense of belongingness" and "sense of community", as well as the feeling that an individual is part of a community, is one of the most important basic needs of a human. Citizen affinities may be based on shared interests, common problem solving, etc.; they may be associated with processes in the common space, as well as with processes that are not directly related to a specific location.

Social interaction of individuals - in the context of territorial community formation, the basis of interaction is everyday neighbouring, starting with polite greeting and eventually ending with close friendship. The basis of interaction is communication.

David Thomas (Thomas, 1991), who has experience in the formation of communities and is a key executive director at the Community Development Foundation, offers his vision of the territorial community (place-based community) establishment. He underlines the great role of resources and processes that form viable or communication communities: a) which are formed to bring inhabitants together not to alienate from each other; b) where there are social communication stimulation options/mechanisms - cafes, churches, stores, pubs, community centres, etc.; c) where there are regular activities that stimulate social interaction, for example, taking children to school on foot, and not by a car; d) where there is a different "live" social and recreational network, as well as a network based on mutual support; e) where there are various active types of organisations with different aims that bring people together as well as define and represent their ideas and problems; f) that allow inhabitants to undertake social roles outside their households - roles that satisfy these inhabitants and serve as the basis for other inhabitants (Fig. 1). These are the aspects that should be taken into account when analysing the creation of communities in a certain neighbourhood."

Towards an even deeper understanding of community development, Thomas has created the community interaction scale, which is divided into two blocks and 
grouped into grades from 1 to 11 (Fig. 1). The scale consists of grades that are separated, because they distinguish between lower, regular and obvious community interaction aspects (from 1 to 6) and higher/more complex and formal organisational aspects of community life (from 7 to 11 ).

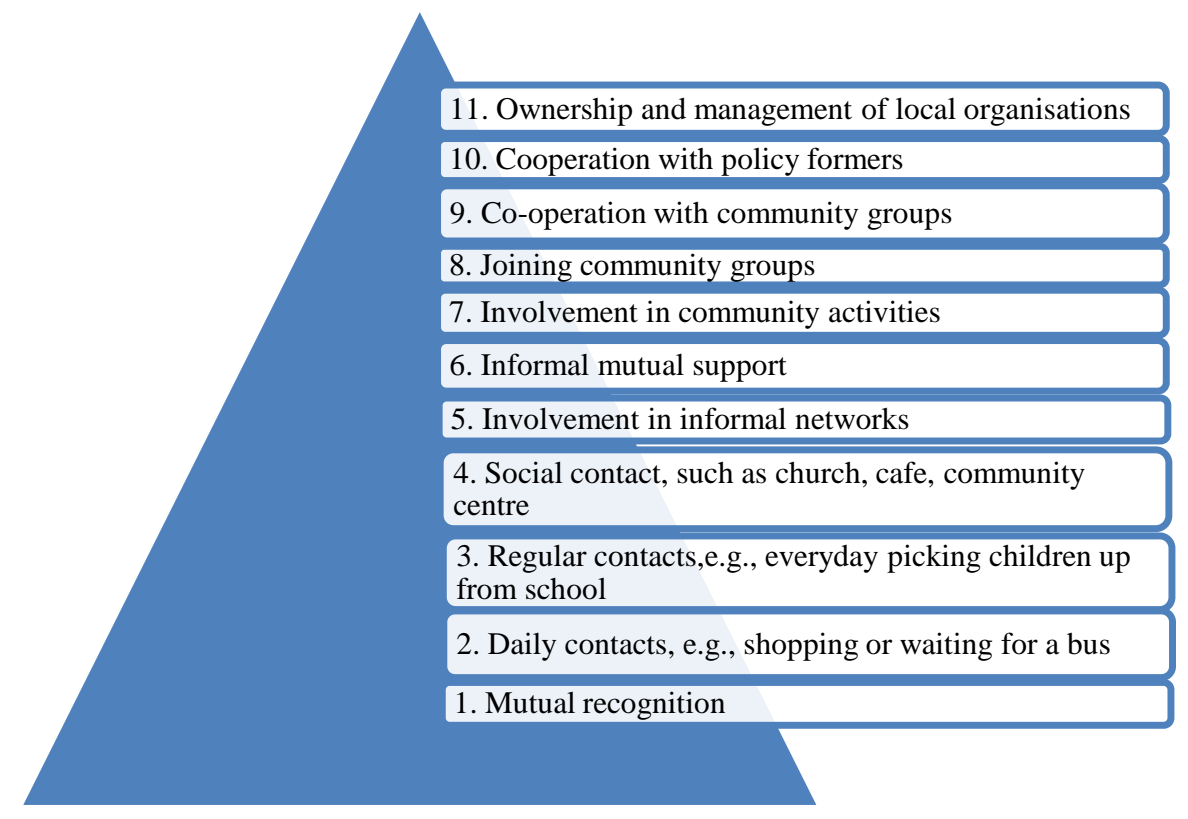

Fig. 1. Community interaction scale (Ušča, 2013) (Figure created by authors).

Taking into account that historically in Latvia, the villages have not formed as built-up areas but, among other things, are based on interpersonal ties and needs, as well as in theory, such territorial limitation forms a community, further in the present study the authors will examine the integrated development of villages and communities or territorial communities that have a clearly defined operational limitation.

\subsection{Principles of Sustainable Development}

In the process of long-term development planning, it is assumed to use the following concepts:

1) 'sustainable development' (Ministry of Environmental Protection and Regional Development, 2016) - the concept defined in the report of the World Commission on Environment and Development "Our Common Future" and widely used internationally since the 1992 United Nations Conference "Environment and Development" in Rio de Janeiro. Sustainable development is explained as "development that ensures satisfaction of present needs, without endangering the needs of future generations". Sustainable development has been characterised by three interlinked dimensions: environmental, economic, and social. This means that strict environmental protection requirements and high economic performance are not contradictory, i.e., the economic growth should not lead to 
environmental degradation and, at the same time, should provide a high quality of life;

2) 'balanced development' (Legislation of the Republic of Latvia, 2008) development is planned by balancing separate area progress levels and rates;

3) territorial cohesion' (European Commission, 2008) - its objective is to achieve harmonious progress in all inhabited territories and ensure that inhabitants can make optimal use of these territories;

4) 'territorial cohesion, sustainable and balanced development' are planned at regional and local level. There is a common opinion that the development strategy should be created taking into account the assets of a particular territory - physical, human and social capital -, as well as natural resources.

To ensure the quality of sustainable development planning, it is necessary to choose an appropriate growth theory for a particular situation and territory, which would be focused on a full-fledged human capital and other resources; therefore, further in the paper, a new economic growth theory is examined.

In order to ensure the planned development strategy compliance with the concepts above, the authors have chosen the new economic growth theory as the basis, because it is the most suitable for the current economic situation and the level of development in Latvia.

In the economic theories already in the 1970s, an attempt was undertaken to introduce an important factor - human resources. However, later, the research and development factor was introduced (Audretsch, Keilbach \& Lehmann, 2006). For many years the outdated economic theories have been adapted to the real market situation. The main factor that should be understood by the entrepreneurs is that the economic development is in their hands - they own the physical capital, and, what is most important, they own knowledge and human resources.

The new economic growth theory is based on the idea that each country or region should look for its own path of technology development. It means that it is necessary to achieve the technological progress appropriate for a particular environment, nature and human knowledge, because customization of technology from other regions implies the repetition of the old and already used ideas. Modern buyers are mainly interested in innovative, effective and possibly less expensive products or services that meet the expected quality requirements. However, this result can be achieved only with new ideas, technologies and an efficient use of materials and management of human resources.

The new economic growth theory is based on a knowledge-based economy, in which a key resource is a human who is well-trained, ready to acquire new knowledge, as well as expresses self-initiative and readiness to share innovative ideas (Audretsch, Keilbach \& Lehmann, 2006). According to the above-mentioned observations, it can be concluded that small and medium-sized enterprises are particularly important for the knowledge-based economy, because they need to improve their operational efficiency in order to be able to develop and function. Within the framework of these theories, the state supports small and medium-sized enterprises, because they are unable to introduce new technologies on their own but usually have a lot of innovative and new solutions, which later (in the 
implementation of policy) will bring to the state comparatively more money than that initially invested.

Taking into account that the economic theory focuses on a narrow vision of development (but corresponds to the National Development Plan of Latvia for 2020), in the next section the authors explore the preconditions to be included in the planning documents that will promote not only the economic growth but also the social and environmental development.

\subsection{National Legislation}

In the Republic of Latvia, all regulations are issued in a hierarchical system; for this reason, the highest documents are laws, in addition to which regulations by the Cabinet of Ministers are issued, but they are interpreted by methodical recommendations.

In the Republic of Latvia, regional development planning is regulated by the Regional Development Law (Legislation of the Republic of Latvia, 2002), which aims to encourage and ensure a balanced and sustainable development of the country, considering all the features and possibilities of the whole national territory and its separate parts to reduce disparity between them, as well as to maintain and develop the natural and cultural characteristics and the development potential of each area. The Law puts forward the following requirements for development planning documents at local authorities:

1) regional development shall be implemented in conformity with the following mutually co-ordinated state and regional development planning documents: National Development Plan, National Spatial Plan, Regional Policy Guidelines, sectoral development programmes, development programmes and spatial plans of planning regions, development programmes and spatial plans of local governments, development programmes and spatial plans of territorial local governments;

2) the development programme of local governments is a long-term (twelve years) regional policy planning document, which specifies the development priorities of the relevant district local government. The development programme of a planning region shall be developed and implemented in accordance with the territorial spatial plan of the given district local government.

The general provisions and economic basis for the activities of the local governments of Latvia are set out by the Law "On Local Governments" (Legislation of the Republic of Latvia, 1994), which also stipulates the competences of local governments, councils and their institutions, as well as the rights and responsibilities of the chairpersons of city or municipality councils, the relations of local governments with the Cabinet of Ministers and ministries, as well as the general provisions for relations among local governments. The Law puts forward the following requirements for development planning documents at local authorities:

1) a local government shall develop the local municipality development programme and spatial plan, local plans, detailed plans and thematic plans, 
ensure the implementation of the territorial development programme as well as the territorial planning administrative supervision;

2) the council has the right to approve the local municipality territorial development programme and spatial plan.

In the Republic of Latvia, regional development planning is regulated by the Development Planning System Law (Legislation of the Republic of Latvia, 2008), which aims to promote a sustainable and stable development of the local government, as well as improve the quality of life of inhabitants by determining the development planning system. The Law puts forward the following requirements for development planning documents at local authorities:

1) the objectives and the results to be reached in the field of relevant policy or territory shall be proposed, the determined problems shall be described and their solutions shall be provided, the possible impact of these solutions shall be evaluated, as well as further action necessary for the implementation of the policy and assessment of results shall be planned in the development planning document;

2) development shall be planned for the long term (up to 25 years), medium term (up to seven years) and short term (up to three years), as well as planning documents shall be drawn up for taking a conceptual decision or definition of the national position;

3 ) the development planning documents of local level are subordinated hierarchically to the regional and national level development planning documents. The development planning documents of regional level are subordinated hierarchically to the national level development planning documents.

Based on the information provided in this section, the authors conclude that in Latvia there are enough laws that regulate the enforcement of the previously viewed principles needed for a sustainable and balanced development - society involvement, control mechanisms and mutual commitment of documents. At the same time, it has been ascertained that in Latvia the development planning system does not provide a lower level of planning, i.e., at the level of municipality, and the involvement of society is mostly envisaged in a formal way.

\subsection{International Context}

Community development is an important stage of spatial planning, which has been thoroughly studied in the UK (Turner, 2009). It has been examined less extensively in the USA (Vitiello \& Wolf-Powers, 2014), Australia (Campbell \& Hunt, 2013) and Ireland (Gaynor, 2011), as well as in such developing countries as Cameroon (Alasah, 2011), Indonesia (Kenny, Fanany, \& Rahayu, 2013), China (Chan, 2013), etc.

After the collapse of the Soviet Union, particular attention was devoted to the communities in the post-Soviet countries, as well as to the study of their development principles, for example, Georgia (Vasadze \& Datuashvili, 2011), Ukraine (Williams, Nadin, Rodgers, \& Round, 2012) and Lithuania (Macken- 
Walsh, 2009) were examined. There are only a few studies that deal with the development of the Latvian communities.

\section{PRACTICAL RESEARCH ON VILAGE PLANNING AND COMMUNITY INVOLVEMENT IN LATVIA}

\subsection{Local Planning Process}

In order to interpret the Development Planning System Law (Legislation of the Republic of Latvia, 2008), which states that the Cabinet of Ministers shall, as far as it is not otherwise provided for in the Law, determine the development planning documents of all levels, types and terms, the content to be included therein, the procedures for drawing up, approval, updating, becoming invalid and term of validity thereof, as well as the procedures for the provision of the relevant reports and public participation, the Regulation No.970 "Procedures for the Public Participation in the Development Planning Process" (Legislation of the Republic of Latvia, 2009) was approved on 25 September 2009, which prescribed that public participation was possible in the following stages of the development planning process:

1) the proposing of a development planning process (including detection of problems and determination of policy alternatives);

2) the drawing up of a development planning document;

3) the decision-making process according to the procedures stipulated by the decision-making institution;

4) the introduction of a development planning document;

5) the supervision and evaluation of the introduction of a development planning document;

6) the updating of a development planning document.

In the present study, the planning procedure is based on the "Methodological Material for Territorial Development Planning" (Ministry of Regional Development and Local Government Affairs, 2008) by the Ministry of Regional Development and Local Government Affairs (now - the Ministry of Environmental Protection and Regional Development).

The methodological material has been drawn up on the basis of the international experience and the results of Latvian planning, monitoring and evaluation system survey carried out by the OECD LEED experts, practitioners and researchers and the Ministry of Regional Development and Local Government Affairs (2008).

According to the methodological material, territorial development planning is carried out in three stages:

1) mobilisation of the region;

2) development of the planning document;

3) evaluation of the results of the planning document and the performance improvements. 
The mobilisation cycle illustrated in Fig. 2 indicates the actions to be taken before drafting the development document in order to ensure the transparency of the process and the comprehensibility of the direct beneficiaries - citizens and entrepreneurs.

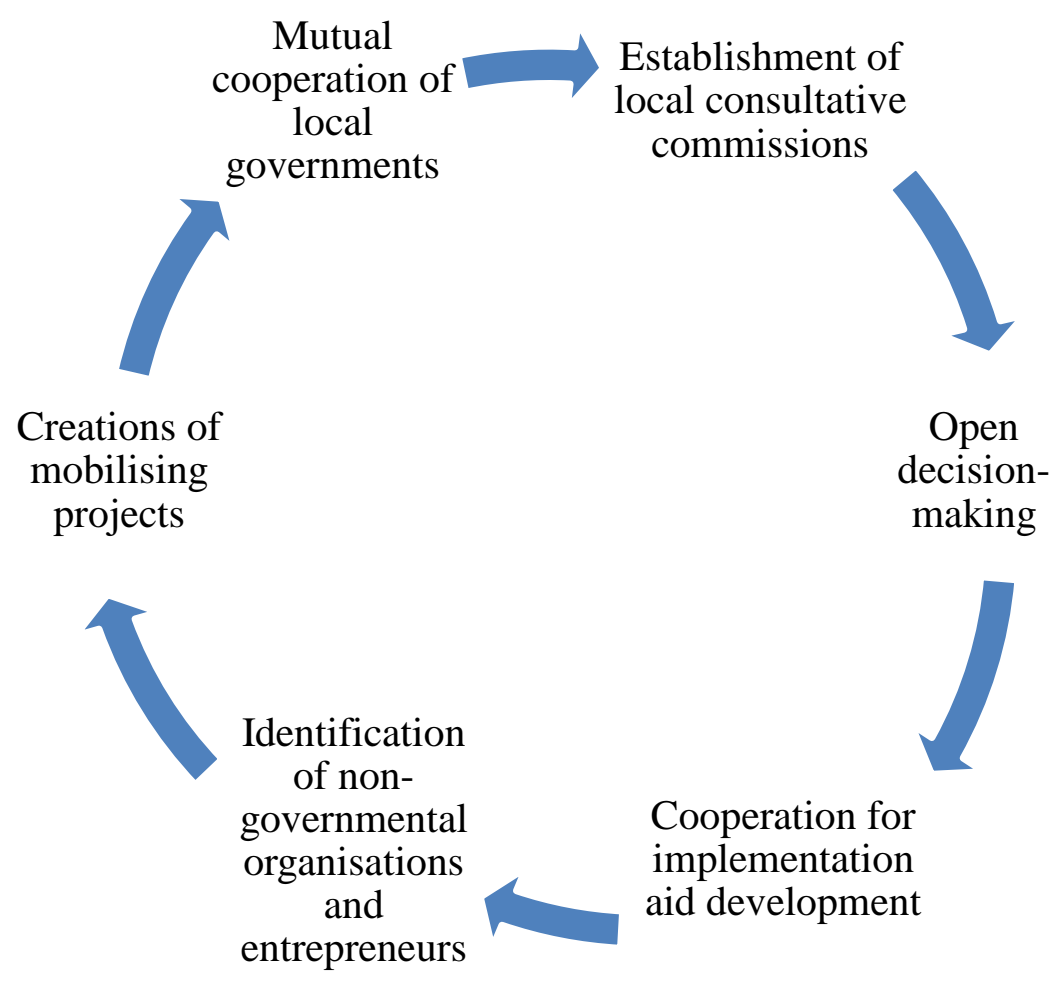

Fig. 2. Mobilisation cycle of a region (Ministry of Regional Development and Local Government Affairs, 2008) (the figure created by the authors).

\subsection{Process Variety}

For a detailed analysis of the interrelation between the mobilisation cycle stages and the opportunities for public involvement, the authors have developed three different models of engagement, as well as have analysed the strengths and weaknesses of these models.

\subsubsection{Formal Model}

The formal model is based on the process fully controlled by an authority, which results in a formally approved document, the implementation of which is ensured by a municipality itself; all participants are included in the formal planning documents and are not focused on public participation. The authors have developed the stage sequence of the formal planning model, as well as have identified its strengths and weaknesses (Table 1). 
Table 1. Formal Planning Model (developed by the authors)

\begin{tabular}{|c|c|c|}
\hline Stage & Strengths & Weaknesses \\
\hline $\begin{array}{l}\text { Mobilisation } \\
\text { The local government invites } \\
\text { the village representatives to } \\
\text { participate in the planning } \\
\text { process, disseminate } \\
\text { information in formal way } \\
\text { (website, newspaper, etc.). }\end{array}$ & $\begin{array}{l}\text { Widely available resources } \\
\text { for the dissemination of } \\
\text { information. } \\
\text { Available communication } \\
\text { contacts with citizens. }\end{array}$ & $\begin{array}{l}\text { There is no direct daily } \\
\text { contact with potential } \\
\text { participants, which may cause } \\
\text { "power distance". * } \\
\text { Informal communication } \\
\text { channels are not used. }\end{array}$ \\
\hline $\begin{array}{l}\text { Planning } \\
\text { The local government, based } \\
\text { on statistical research, modern } \\
\text { solution identification and } \\
\text { clustering of working groups, } \\
\text { prepares the documents that } \\
\text { are publicly discussed and } \\
\text { approved within the } \\
\text { framework of laws and } \\
\text { regulations. }\end{array}$ & $\begin{array}{l}\text { Resources are available for } \\
\text { extensive statistical research. } \\
\text { Resources are available for } \\
\text { research in various } \\
\text { industries, attracting both } \\
\text { local and foreign specialists. } \\
\text { Possible exchange of } \\
\text { experience by using gathered } \\
\text { contacts. }\end{array}$ & $\begin{array}{l}\text { The use of formalised } \\
\text { procedures. } \\
\text { The lack of knowledge about } \\
\text { specific problems in a } \\
\text { specific place. } \\
\text { Formal discussion of } \\
\text { documents, as well as reliance } \\
\text { on the laws and regulations } \\
\text { that in case of Latvia are } \\
\text { often fragmented, outdated or } \\
\text { obsolete, or there is no } \\
\text { available funding or other } \\
\text { resources to introduce the } \\
\text { regulations (policy } \\
\text { implementation documents } \\
\text { are not made accessible in the } \\
\text { resources available). }\end{array}$ \\
\hline $\begin{array}{l}\text { Implementation } \\
\text { In accordance with the } \\
\text { approved action plan and } \\
\text { funding plan, the local } \\
\text { government ensures the } \\
\text { implementation of activities. }\end{array}$ & $\begin{array}{l}\text { There are public resources } \\
\text { available for the } \\
\text { implementation of activities. } \\
\text { There are tangible and } \\
\text { intangible assets available to } \\
\text { ensure the place for the } \\
\text { implementation of activities. }\end{array}$ & $\begin{array}{l}\text { Restrictions on the activities } \\
\text { directed towards the } \\
\text { regulation of statutory acts. } \\
\text { Not being "on the site" ** } \\
\text { makes it difficult to identify } \\
\text { the most effective solution. }\end{array}$ \\
\hline $\begin{array}{l}\text { Monitoring } \\
\text { In accordance with the } \\
\text { regulations, the local } \\
\text { government draws up regular } \\
\text { reports on the progress, } \\
\text { informs the Council about the } \\
\text { reports, and publishes the } \\
\text { reports online. }\end{array}$ & $\begin{array}{l}\text { The data are made available, } \\
\text { as well as there are } \\
\text { restricted-access databases. } \\
\text { There are specialists to } \\
\text { perform the work, and the } \\
\text { necessary capacity is } \\
\text { ensured. }\end{array}$ & $\begin{array}{l}\text { A difficult-to-manage and } \\
\text { slow (change) management } \\
\text { process. } \\
\text { Formal reports based on data } \\
\text { collection. }\end{array}$ \\
\hline
\end{tabular}

* "Power distance" - obedience of persons at one organisation or institution to the dominant view of other organisations or institutions.

** Not being "on the site" - not living in a community on a daily basis, lack of knowledge of the community daily processes. 
According to Table 1, the local planning process through a formal model of sequence is very formal, which is not possible within the framework of full mobilisation of the village, as well as development is based on formal data analysis and regulatory framework. Although this model provides resources for the implementation of activities, it does not always provide the most effective and appropriate solutions to achieve the objectives of activities. At the same time, relying on other regulatory acts - the policy planning documents - is closely associated with the document topicality and availability or the lack of resources for the implementation of policy initiatives.

\subsubsection{Informal Model}

The informal model is based on the process fully controlled by local society, which results in an informal plan, the implementation of which is ensured by the village society but its planning documents are drawn up by the local government. Stage sequence, and the strengths and weaknesses of the informal planning model are demonstrated in Table 2.

According to the informal planning model, the local territory planning process is informal, within which it is not possible to be fully confident about the legitimacy of the decisions made. Within this process, there is a high risk that the planned activity is based on emotional judgments, without taking into account the evaluation of an overall development context. There is a danger that the planned activities will not have sufficient resources for their implementation.

Table 2. Informal Planning Model (developed by the authors)

\begin{tabular}{|c|c|c|}
\hline Stage & Strengths & Weaknesses \\
\hline $\begin{array}{l}\text { Mobilisation } \\
\text { Inside the village, residents } \\
\text { are invited to joint meetings } \\
\text { through informal channels. }\end{array}$ & $\begin{array}{l}\text { Direct access to } \\
\text { communication with the local } \\
\text { community. } \\
\text { Ability to use any informal } \\
\text { communication channels. }\end{array}$ & $\begin{array}{l}\text { There is no confidence that } \\
\text { the information is spread } \\
\text { steady to all citizens, as well } \\
\text { as whether the information is } \\
\text { not spread to a closed society. }\end{array}$ \\
\hline $\begin{array}{l}\text { Planning } \\
\text { Planning "from scratch" } \\
\text { where there is focus on local } \\
\text { issues and through discussion } \\
\text { the best solutions are found. } \\
\text { A document (or a decision) is } \\
\text { adopted within a certain } \\
\text { group as a result of inner } \\
\text { agreement. }\end{array}$ & $\begin{array}{l}\text { Possibility of generating any } \\
\text { kind of ideas that are up-to- } \\
\text { date at the given moment. } \\
\text { There is a possibility of } \\
\text { extensive discussion } \\
\text { undertaken by local "opinion } \\
\text { leaders". }\end{array}$ & $\begin{array}{l}\text { There is no clear legal status } \\
\text { of decision. } \\
\text { There is no clear } \\
\text { substantiation and usefulness } \\
\text { of discussion. } \\
\text { There is a risk that the } \\
\text { planning "from scratch" can } \\
\text { cause great mutual conflicts. } \\
\text { There is a possibility that the } \\
\text { village plan is developed not } \\
\text { taking into account the } \\
\text { overall administrative } \\
\text { territory development vision. }\end{array}$ \\
\hline
\end{tabular}




\begin{tabular}{|l|l|l|}
\hline \multicolumn{1}{|c|}{ Stage } & \multicolumn{1}{|c|}{ Strengths } & \multicolumn{1}{c|}{ Weaknesses } \\
\hline $\begin{array}{l}\text { Implementation } \\
\text { Local community ensures the } \\
\text { implementation of the plan } \\
\text { using its own or attracted } \\
\text { resources, searching for } \\
\text { solutions "on the spot". Local } \\
\text { government, which is focused } \\
\text { on achieving its goals, is not } \\
\text { involved in the } \\
\text { implementation process. }\end{array}$ & $\begin{array}{l}\text { There is no relation with } \\
\text { regulatory limitations; } \\
\text { therefore, there is an } \\
\text { opportunity to search for the } \\
\text { most effective and appropriate } \\
\text { solution. }\end{array}$ & $\begin{array}{l}\text { There are no clear } \\
\text { implementation resources and } \\
\text { their availability is limited - } \\
\text { financial, physical and } \\
\text { intangible assets. }\end{array}$ \\
$\begin{array}{l}\text { There is a possibility of being } \\
\text { flexible and adapting to } \\
\text { circumstances. }\end{array}$ & $\begin{array}{l}\text { There are no permanent } \\
\text { resources to ensure the } \\
\text { implementation process; there } \\
\text { is a risk that the } \\
\text { implementation process is } \\
\text { fragmented and purposeless. }\end{array}$ \\
\hline $\begin{array}{l}\text { Monitoring } \\
\begin{array}{l}\text { Informal monitoring, which } \\
\text { can be defined; outcome } \\
\text { indicators can be the results } \\
\text { of the activities. }\end{array}\end{array}$ & $\begin{array}{l}\text { Informal monitoring that } \\
\text { allows very quickly } \\
\text { responding to the changes } \\
\text { required under particular } \\
\text { conditions. }\end{array}$ & $\begin{array}{l}\text { It is not clear what the } \\
\text { process of change } \\
\text { management would be and } \\
\text { whether broad public } \\
\text { involvement would be } \\
\text { ensured in the process of } \\
\text { changes. }\end{array}$ \\
\hline
\end{tabular}

\subsubsection{Composite Model}

The local government promotes the progress of the process, providing support for the development, as well as participates in the implementation of activities, but the co-responsibility of the implementation of the activities (including the implementation of the activities) is also undertaken by the local community. The stage sequence, and the strengths and weaknesses of the composite model are provided in Table 3.

According to Table 3, the composite planning model is considered to be the most successful one out of all village (local area) planning models, because the widest possible interested audience is involved, at the same time creating informal cooperation and decision-making procedures. Within this model, it is important to agree on the specific format of cooperation between formal and informal parties in order to have the opportunity for necessary compromises (taking into account the regulatory framework applicable to the formal parties). 
Table 3. Composite Planning Model (developed by the authors)

\begin{tabular}{|c|c|c|}
\hline Stage & Strengths & Weaknesses \\
\hline $\begin{array}{l}\text { Mobilisation } \\
\text { The local government, in } \\
\text { cooperation with formal and } \\
\text { informal representations of a } \\
\text { village (groups or } \\
\text { organisations), establishes an } \\
\text { institutional group of } \\
\text { interested parties that } \\
\text { participate in the creation of } \\
\text { the document. Information is } \\
\text { disseminated in a formal and } \\
\text { informal way. }\end{array}$ & $\begin{array}{l}\text { It is possible to use the most } \\
\text { extensive information } \\
\text { dissemination channels - both } \\
\text { formal and informal, providing } \\
\text { access to information and } \\
\text { possibility that the widest } \\
\text { interested audience will } \\
\text { express their views. }\end{array}$ & $\begin{array}{l}\text { It is necessary to ensure a } \\
\text { tight control over the } \\
\text { information flow to avoid its } \\
\text { distortion before it reaches } \\
\text { the end user. }\end{array}$ \\
\hline $\begin{array}{l}\text { Planning } \\
\text { Local government, based on } \\
\text { the vision of the development } \\
\text { of the whole area and the } \\
\text { evaluation of the needs of a } \\
\text { particular village, puts } \\
\text { forward proposals for the } \\
\text { development plan, which is } \\
\text { discussed within the given } \\
\text { stage. }\end{array}$ & $\begin{array}{l}\text { There is possibility of using the } \\
\text { data collected by the local } \\
\text { government, as well as of using } \\
\text { municipal resources to ensure } \\
\text { the implementation of the } \\
\text { process. } \\
\text { There is a free form of the final } \\
\text { document because the progress } \\
\text { of the process is a mutual } \\
\text { agreement of process } \\
\text { facilitators. } \\
\text { It is possible to find a } \\
\text { compromise on any issue } \\
\text { because the decision-making } \\
\text { process is based on } \\
\text { compromises and persuasion. }\end{array}$ & $\begin{array}{l}\text { A strong } \\
\text { management is neecess } \\
\text { because there are a large } \\
\text { number of parties and } \\
\text { interests involved; at the } \\
\text { same time, emotional and } \\
\text { local recommendations are } \\
\text { possible, which generally } \\
\text { contradicts the common } \\
\text { principles of spatial } \\
\text { development. }\end{array}$ \\
\hline $\begin{array}{l}\text { Implementation } \\
\text { In the plan, both the needs of } \\
\text { society and local government } \\
\text { policy are consolidated; the } \\
\text { policy shall be divided into } \\
\text { activities enforceable to each } \\
\text { party. }\end{array}$ & $\begin{array}{l}\text { Collaboration among the } \\
\text { integrators of activities as well } \\
\text { as their simultaneous (parallel) } \\
\text { work, which could contribute } \\
\text { to faster implementation of the } \\
\text { plan within the time limit, is } \\
\text { made possible. } \\
\text { The most effective ways of } \\
\text { implementing the activities are } \\
\text { searched for because the formal } \\
\text { procedures are not obligatory } \\
\text { for all the integrators. }\end{array}$ & $\begin{array}{l}\text { Strong process management } \\
\text { is needed because a large } \\
\text { number of parties and } \\
\text { interests are involved. }\end{array}$ \\
\hline $\begin{array}{l}\text { Monitoring } \\
\text { The defined socio-economic } \\
\text { and outcome indicators are } \\
\text { monitored by all parties and } \\
\text { adjusted in collaboration. }\end{array}$ & $\begin{array}{l}\text { It is possible to freely select the } \\
\text { form of supervision and } \\
\text { procedures, as well as there is a } \\
\text { possibility of delegating the } \\
\text { monitoring and change } \\
\text { function to the citizens of the } \\
\text { village, who can at once } \\
\text { respond to new actual } \\
\text { conditions. }\end{array}$ & $\begin{array}{l}\text { If monitoring is not } \\
\text { performed by a strong leader, } \\
\text { then it is possible that } \\
\text { changes are made chaotically } \\
\text { or without the involvement of } \\
\text { all parties, thus not achieving } \\
\text { the necessary village } \\
\text { development goals. }\end{array}$ \\
\hline
\end{tabular}




\section{CONCLUSION}

Based on the present research, the following conclusions can be drawn.

1. Regions worldwide and European countries have experience in village planning to foster local development - both through private initiatives and common national policies. At the same time, the planning system of Latvia does not stipulate specific provisions of local (village) development planning.

2. In the planning system of Latvia, the village development level is not envisaged, although the local society is best aware of its local problems and is able to find the most effective solutions to prevent them. At the same time, it should be taken into account that the highest added value to the village planning (including the implementation of plans) can be provided by mutual cooperation, because both parties have their own advantages (for example, local society - knowledge of local problems; local municipality - material and non-material resources). The use of common advantages in combination with a qualitative administration could provide better solutions, as well as increase the life quality of village citizens and satisfaction with their residence.

3. Based on the regulatory framework and national guidance materials, as well as regional mobilisation cycle, the authors have developed three models of community involvement - formal, informal, and composite. The research has demonstrated that using the composite community involvement model for village development planning and involving a wider range of parties interested in village development, it is possible to obtain the widest range of views (and the needs), promote shared public responsibility of the village development, as well as find the most effective (in financial terms as well) solutions, which could considerably increase the satisfaction of village citizens with the living space in the future.

\section{REFERENCES}

Alasah, A. A. (2011). The impact of government policy on grassroots level community development initiative in Northwest region of Cameroon. Community Development Journal, 46(2), 196-212. http://dx.doi.org/10.1093/cdj/bsp061

Audretsch, D. B., Keilbach, M. C., Lehmann, E. E. (2006). Entrepreneurship and Economic Growth. The Great Britain: Oxford University Press. http://dx.doi.org/10.1093/acprof:oso/9780195183511.001.0001

Campbell, D., \& Hunt, J. E. (2013). Achieving broader benefits from Indigenous land use agreements: community development in Central Australia. Community Development Journal, 48(2), 197-214. http://dx.doi.org/10.1093/cdj/bss036

Chan, C. K. (2013). Community-based organizations for migrant workers' rights: the emergence of labour NGOs in China. Community Development Journal, 48(1), 6-22. http://dx.doi.org/10.1093/cdj/bss001

European Commission. (2008). Zaḷā grāmata par teritoriālo kohēziju - Teritoriālās daudzveidības priekšrocību izmantošana [Green Paper on Territorial Cohesion, the way ahead - Turning territorial diversity into an asset]. Panorama, 28. Retrieved from http://ec.europa.eu/regional_policy/lv/information/publications/panorama-magazine/2008/panorama-28green-paper-on-territorial-cohesion-the-way-ahead

Gaynor, N. (2011). In-Active citizenship and the depoliticization of community development in Ireland. Community Development Journal, 46(1), 27-41. http://dx.doi.org/10.1093/cdj/bsp038

Kavacs, J. (2015). Ciema jēdziena vēsturiskā attīstība [Village Concept Historical Development]. Retrieved from map.lgia.gov.lv/file.php?id=217

Kenny, S., Fanany, I., \& Rahayu, S. (2013). Community development in Indonesia westernization or doing it their way? Community Development Journal, 48(2), 280-297. http://dx.doi.org/10.1093/cdj/bss053 
Kusenbach, M. (2008). A Hierarchy of Urban Communities: Observations on the Nested Character of Place. City \& Community, 7(3), 225-249. http://dx.doi.org/10.1111/j.1540-6040.2008.00259.x

Latviešu Konversācijas vārdnīca [Latvian Conversation Dictionary]. (1928-1929). XVI copybook, column 3901.

Latvijas padomju enciklopēdija [Soviet Latvia dictionary]. (1982). 2, 265.

Legislation of the Republic of Latvia. (1994). Likums "Par pašvaldībām” [Law "On Local Governments"]. Retrieved from http://likumi.lv/doc.php?id=57255

Legislation of the Republic of Latvia. (2002). Regionālās attīstības likums [Regional Development Law]. Retrieved from http://likumi.lv/doc.php?id=61002

Legislation of the Republic of Latvia. (2008). Attīstības plānošanas sistēmas likums [Development Planning System Law]. Retrieved from http://likumi.lv/doc.php?id=175748

Legislation of the Republic of Latvia. (2009). Sabiedrības lìdzdalības kārtība attīstības plānošanas procesā [Procedures for the Public Participation in the Development Planning Process]. Regulation Nr. 970. Retrieved from http://likumi.lv/doc.php?id=197033

Legislation of the Republic of Latvia. (2011). Administratīvo teritoriju un apdzìvoto vietu likums [Law on Administrative Territories and Populated Areas]. Retrieved from http://likumi.lv/doc.php?id=185993

Macken-Walsh, A. (2009). Post-socialist community action in Lithuania. Community Development Journal, 44(4), 515-524. http://dx.doi.org/10.1093/cdj/bsn007

Ministry of Environmental Protection and Regional Development. (2016). Ilgtspējīga attīstība [Sustainable development]. Retrieved from http://www.varam.gov.lv/lat/darbibas_veidi/ilgtspejiga_attistiba/

Ministry of Regional Development and Local Government Affairs. (2008). Metodiskais materiāls teritorijas attīstības plānošanai [Methodological material for territorial development planning]. Retrieved from http://www.varam.gov.lv/lat/darbibas_veidi/reg_att/metodika/

Thomas, D. (1991). Community Development at Work: A Case of Obscurity in Accomplishment. London: Community Development Foundation.

Turner, A. (2009). Bottom-up community development: reality or rhetoric? The example of the Kingsmead Kabin in East London. Community Development Journal, 44(2), 230-247. http://dx.doi.org/10.1093/cdj/bsm047

Ušča, M. (2013). Teritoriālo kopienu veidošanās procesi Rīgā [Territorial communities' formation in the Riga]. (Doctoral Thesis, University of Latvia). Retrieved from https://luis.lu.lv/pls/pub/luj.fprnt?l=1\&fn=F109931341/Maija\%20Usca\%202013.pdf

Vasadze, N., \& Datuashvili, E. (2011). Community in post-Soviet Georgia: experiences and challenges. Community Development Journal, 46(1), 138-141. http://dx.doi.org/10.1093/cdj/bsq053

Vitiello, D., \& Wolf-Powers, L. (2014). Growing food to grow cities? The potential of agriculture for economic and community development in the urban United States. Community Development Journal, 49(4), 508523. http://dx.doi.org/10.1093/cdj/bst087

Williams, C., Nadin, S., Rodgers, P., \& Round, J. (2012). Rethinking the nature of community economies: some lessons from post-Soviet Ukraine. Community Development Journal, 47(2), 216-231. http://dx.doi.org/10.1093/cdj/bsq064

\section{AUTHORS' SHORT BIOGRAPHIES}

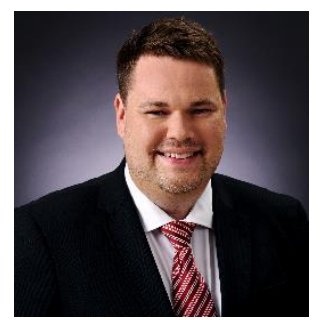

Edgars Pudzis is a $\mathrm{PhD}$ student at the Faculty of Engineering Economics and Management of Riga Technical University. He has obtained the Master's degree in project management from Latvia University of Agriculture and in spatial planning from the University of Latvia.

E. Pudzis gained his work experience both in private sector and in public administration, including several years of running the Carnikava Municipality Development Department, where he paid particular attention to the development of village communities. His research activities are related to regional and local development - local and area short-term and long-term sustainable development, and support to local community initiatives. He was a member of the Council of Latvia Rural Forum. At present, he runs the Local Action Group of the Carnikava and Saulkrasti District Municipalities.

Since 2015, E. Pudzis is a Lecturer in Project Management at the University of Latvia and BA School of Business and Finance.

ORCID iD: http://orcid.org/0000-0003-3842-0126 


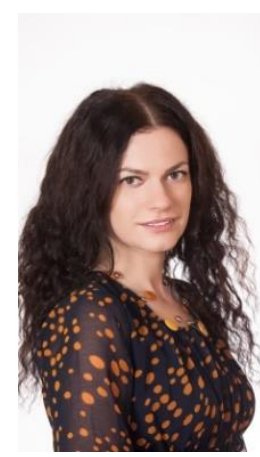

Sanda Geipele, Dr. oec., Assist. Prof., Senior Researcher at Riga Technical University, Latvia. For more than five years she worked as a Chief Economist at Riga City Council's Municipal Revenue Department, where her work was related to real estate tax administration. Her research interests include sustainability development problems of real estate market, construction industry, including land use management and institutional economics. She is the author and co-author of 56 scientific publications, including the scientific monograph "Management System of Real Estate Market Development in Latvia" (2015), two monographs with co-authors "Models of Financing Housing Fund Renovation in Latvia" (2012), "SocioEconomic Aspects of the Interaction of Urban and Regional Development" (2012). Since 2010, she has participated in more than 16 scientific conferences and 6 international scientific and practical projects. Sanda Geipele is an expert in management and economic sciences of the Latvian Council of Science.

ORCID iD: http://orcid.org/0000-0002-4721-5944

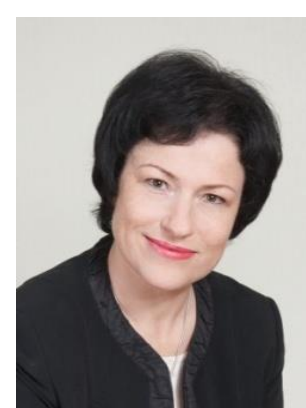

Ineta Geipele is a Professor at the Faculty of Engineering Economics and Management, the Director of the Institute of Civil Engineering and Real Estate Economics, Head of the Department of Civil Construction and Real Estate Economics and Management of Riga Technical University (RTU), Latvia. She obtained the Doctor's degree in economics and Master's degree in economics from RTU. She perfected her professional skills in Austria, Germany, Denmark and England. She is the author and co-author of more than 284 scientific publications. Her current research interests are focused on sustainability development problems of real estate market, construction industry, including land use management and institutional economics. She is an expert in management science of the Latvian Council of Science, a board member of the FIABCI-Baltic Multinational Chapter, Cunfte of the Facility Management of Latvian Housing and a member of the Latvian Union of Civil Engineers.

ORCID iD: http://orcid.org/0000-0002-2963-087X 